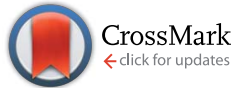

Cite this: Chem. Sci., 2016, 7, 4624

Received 10th February 2016 Accepted 8th April 2016

DOI: $10.1039 / \mathrm{c} 6 \mathrm{sc} 00632 \mathrm{a}$

www.rsc.org/chemicalscience

\section{Steric control of redox events in organo-uranium chemistry: synthesis and characterisation of $U(v)$ oxo and nitrido complexes $\uparrow$}

\author{
Nikolaos Tsoureas, ${ }^{a}$ Alexander F. R. Kilpatrick, ${ }^{\text {b }}$ Christopher J. Inman ${ }^{\text {a }}$ \\ and F. Geoffrey N. Cloke*a
}

\begin{abstract}
The synthesis and molecular structures of a $U(v)$ neutral terminal oxo complex and a $U(v)$ sodium uranium nitride contact ion pair are described. The synthesis of the former is achieved by the use of ${ }^{t} \mathrm{BuNCO}$ as a mild oxygen transfer reagent, whilst that of the latter is via the reduction of $\mathrm{NaN}_{3}$. Both mono-uranium complexes are stabilised by the presence of bulky silyl substituents on the ligand framework that facilitate a $2 \mathrm{e}^{-}$oxidation of a single $\mathrm{U}(\mathrm{III})$ centre. In contrast, when steric hindrance around the metal centre is reduced by the use of less bulky silyl groups, the products are di-uranium, U(IV) bridging oxo and (anionic) nitride complexes, resulting from $1 \mathrm{e}^{-}$oxidations of two U(III) centres. SQUID magnetometry supports the formal oxidation states of the reported complexes. Electrochemical studies show that the $\mathrm{U}(\mathrm{v})$ terminal oxo complex can be reduced and the $[\mathrm{U}(\mathrm{IV}) \mathrm{O}]^{-}$anion was accessed via reduction with $\mathrm{K} / \mathrm{Hg}$, and structurally characterised. Both the nitride complexes display complex electrochemical behaviour but each exhibits a quasi-reversible oxidation at ca. $-1.6 \mathrm{~V} v \mathrm{~s}$. $\mathrm{Fc}^{+/ 0}$.
\end{abstract}

\section{Introduction}

The study of well-defined molecular complexes of uranium is a thriving field of research, ${ }^{1}$ with significant current interest in the activation of small molecules and organic substrates by $\mathrm{U}(\mathrm{III})$ compounds, ${ }^{2}$ the stabilisation of low oxidation states (i.e. $\left.\mathrm{U}(\mathrm{II})^{3}\right)$ and also the study of higher oxidation state complexes featuring $\mathrm{U} \cdots \mathrm{E}\left(\mathrm{E}=\right.$ main group element) multiple bonds. ${ }^{4}$ Historically, complexes featuring $\mathrm{U} \cdots \mathrm{O}$ terminal bonds have been dominated by the ubiquitous uranyl moiety, ${ }^{5}$ partly due to its apparent chemical inertness (although recently disproved ${ }^{6}$ ) and its technological relevance to the nuclear cycle. ${ }^{7}$ In contrast, terminal mono-oxo complexes are much less common partly due to the increased nucleophilicity of the oxo ligand, ${ }^{4 u, 8}$ which leads to the formation of dimeric species, ${ }^{8 a, 9}$ and stabilisation of monomeric $\mathrm{U}=\mathrm{O}$ complexes requires the use of bulky supporting ligands. ${ }^{\mathbf{4}, 10,11,12}$ The relative rarity of uranium terminal oxo complexes is paralleled by the case of terminal nitride uranium complexes, ${ }^{13,14}$ and the majority of unsupported $\mathrm{U} \cdots \mathrm{N}$ bonds are stabilised in dimeric/polymeric structures. ${ }^{15}$ Indeed,

${ }^{a}$ School of Life Sciences, Division of Chemistry, University of Sussex, Falmer, Brighton, BN1 9QJ, UK. E-mail: f.g.cloke@sussex.ac.uk

${ }^{b}$ Chemistry Research Laboratory, Department of Chemistry, University of Oxford, 12 Mansfield Road, OX1 3TA, Oxford, UK

$\dagger$ Electronic supplementary information (ESI) available: Experimental and synthetic procedures, additional X-ray crystallographic, cyclic voltammetry and magnetic data. CCDC numbers 1449997-1450002 for compounds (3), (4), (7), (9), (10), and (11). For ESI and crystallographic data in CIF or other electronic format see DOI: 10.1039/c6sc00632a until 2012 no stable, well-defined uranium terminal nitride complex was known, ${ }^{13}$ although UN triply bonded species had been spectroscopically identified in low temperature matrices, ${ }^{\mathbf{1 6}}$ and in situ generation and involvement in $\mathrm{C}-\mathrm{H}$ activation had been proposed and studied computationally. ${ }^{17}$

We have previously demonstrated the significance of the steric environment around the uranium centre in controlling the reductive coupling of $\mathrm{CO}_{2}$ (ref. 18) and $\mathrm{CO},{ }^{19}$ promoted by $\mathrm{U}(\mathrm{III})$ mixed sandwich complexes of the general type $\left[\mathrm{U}\left\{\eta^{8}-\mathrm{C}_{8} \mathrm{H}_{6}\right.\right.$ $\left.\left.\left(1,4-\mathrm{SiR}_{3}\right)_{2}\right\}\left(\eta^{5}-\mathrm{Cp}^{\mathrm{R}^{\prime \prime}}\right) \mathrm{THF}\right]\left(\mathrm{R}={ }^{\mathrm{i}} \operatorname{Pr}(\mathbf{1}), \mathrm{Me}(2)\right)$. In particular, the reductive transformations (i.e. coupling, disproportionation, or reduction) of $\mathrm{CO}_{2}$ using the complexes $\left[\mathrm{U}\left\{\eta^{8}-\mathrm{C}_{8} \mathrm{H}_{6}-(1,4-\right.\right.$ $\left.\left.\mathrm{SiMe}_{3}\right)_{2}\right\}\left(\eta^{5}-\mathrm{Cp}^{\mathrm{Me}_{4} \mathrm{R}^{\prime}}\right) \mathrm{THF}$ ] (A) can be largely controlled by varying the size of $\mathrm{R}^{\prime}\left(\mathrm{R}^{\prime}=\mathrm{Me}, \mathrm{Et},{ }^{\mathrm{i}} \mathrm{Pr},{ }^{t} \mathrm{Bu}\right) .{ }^{18 a}$ Unlike complexes of type $\mathbf{A}$ that exhibit a clear trend between the effect of steric environment and the outcome of the possible reductive transformations, when the analogous complexes in which the $\mathrm{SiMe}_{3}$ group had been replaced by the bulkier $\operatorname{Si}^{\mathrm{i}} \operatorname{Pr}_{3}$ group were reacted with $\mathrm{CO}_{2}$, either intractable reaction mixtures were obtained or the reductive disproportionation of $\mathrm{CO}_{2}$ was promoted exclusively. ${ }^{18 b}$ In order to better understand this observation, we envisaged that a study of the reactivity towards other heteroallenes (e.g. $\mathrm{RN}=\mathrm{C}=\mathrm{O}$ ) as model substrates for $\mathrm{CO}_{2}$ might be informative. ${ }^{20}$

\section{Results and discussion}

Reaction of a brown-olive green $\mathrm{C}_{6} \mathrm{D}_{6}$ solution of $\left[\mathrm{U}\left\{\eta^{8}-\mathrm{C}_{8} \mathrm{H}_{6}\right.\right.$ $\left.\left.\left(1,4-\mathrm{Si}^{\mathrm{i}} \mathrm{Pr}_{3}\right)_{2}\right\}\left(\eta^{5}-\mathrm{Cp} *\right) \mathrm{THF}\right]$ (1) with a slight excess (1.05-1.1 eq.) 
of ${ }^{t} \mathrm{BuN}=\mathrm{C}=\mathrm{O}$ under an $\mathrm{Ar}$ atmosphere resulted in an immediate colour change to brown red. ${ }^{1} \mathrm{H}-\mathrm{NMR}$ spectroscopy showed complete consumption of (1) and the formation of a new uranium species and free ${ }^{t} \mathrm{BuNC}$ (further confirmed by GC-MS of the trapped volatiles of the reaction mixture). The ${ }^{29} \mathrm{Si}$ $\left\{{ }^{1} \mathrm{H}\right\}$-NMR spectrum of the product displayed a single resonance at $-73 \mathrm{ppm}$, shifted downfield from $-129 \mathrm{ppm}$ in (1) suggesting that a change in the formal oxidation state of the uranium centre of (III) to (V) had taken place, in accordance with the general trend observed by Evans et al. ${ }^{\mathbf{2 1}}$ The mass spectrum was consistent with the formation of the $\mathrm{U}(\mathrm{v})$ terminal oxo complex $\left\{\mathrm{U}\left[\eta^{8}-\mathrm{C}_{8} \mathrm{H}_{6}\left(1,4-\mathrm{Si}^{\mathrm{i}} \mathrm{Pr}_{3}\right)_{2}\right]\left(\eta^{5}-\mathrm{Cp} *\right) \mathrm{O}\right\}(3)$, and was confirmed by $\mathrm{X}-$ ray crystallography (Fig. 1).

The U-O bond length in (3) (1.826(3) $\AA$ ) is shorter than that found in the $\mathrm{U}(\mathrm{v})$ terminal oxo complex $\left[\mathrm{Ph}_{3} \mathrm{PMe}\right]\left[\mathrm{U}(\mathrm{O})\left(\mathrm{CH}_{2^{-}}\right.\right.$ $\left.\left.\mathrm{SiMe}_{2} \mathrm{NR}^{\prime}\right)\left(\mathrm{NR}_{2}^{\prime}\right)_{2}\right](1.847(2) \AA),{ }^{22}$ but similar within esd's to those in the $\mathrm{U}(\mathrm{v})$ complexes $\left[\mathrm{U}(\mathrm{O})\left(\mathrm{NR}_{2}^{\prime}\right)_{3}\right](1.817(1) \AA),{ }^{10}$ $\left[\mathrm{UTREN}^{\mathrm{TIPS}}(\mathrm{O})\right]\left(1.856(6) \quad \AA, \quad \mathrm{TREN}^{\mathrm{TIPS}}=\left[\mathrm{N}\left(\mathrm{CH}_{2} \mathrm{CH}_{2}-\right.\right.\right.$ $\left.\left.\left.\mathrm{NSi}^{\mathrm{i}} \mathrm{Pr}_{3}\right)_{3}\right]^{3}\right),{ }^{11 a}\left[\left(\left({ }^{\mathrm{R}} \mathrm{ArO}\right) \operatorname{tacn}\right) \mathrm{U}(\mathrm{O})\right]\left(1.848(8) \AA ; \mathrm{R}={ }^{t} \mathrm{Bu}, \mathrm{Ad} ; \operatorname{tacn}=\right.$ triazacyclononane) ${ }^{40} \mathrm{Cp}^{*}{ }_{2} \mathrm{U}(\mathrm{O})(\mathrm{ODipp})(1.859(6) \AA$, Dipp $=$ $\left.2,6-{ }^{\mathrm{i}} \mathrm{Pr}_{2}-\mathrm{C}_{6} \mathrm{H}_{3}\right),{ }^{23}\left[\mathrm{OU}\left\{\mathrm{OSi}\left(\mathrm{O}^{t} \mathrm{Bu}\right)_{3}\right\}_{4} \mathrm{~K}\right](1.825(2) \AA)^{12}$ and $\left[\mathrm{NEt}_{4}\right]$ $\left[\text { trans }-\mathrm{U}\left(\mathrm{NR}_{2}{ }^{\prime}\right)_{3}(\mathrm{O}) \mathrm{CN}\right]^{24}$ The $\mathrm{Ct}(\mathrm{COT})-\mathrm{U}-\mathrm{Ct}\left(\mathrm{Cp}^{*}\right)$ angle of $135.27(2)^{\circ}$ is significantly more acute than those found in U(Iv) $\left(137-140^{\circ}\right)$ and $\mathrm{U}(\mathrm{III})\left(150-155^{\circ}\right)$ mixed sandwich complexes supported by these ligands; ${ }^{4 v, 18 a, 19 c, 25}$ the reason for this is not clear but one possible explanation could be to minimise electrostatic repulsion between the anionic ligand and the polarised $\mathrm{U}-\mathrm{O}$ bond. Compound (3) was further characterised by spectroscopic ${ }^{26}$ and analytical techniques (see ESI $\dagger$ ), and Evans method $\left(\mathrm{C}_{7} \mathrm{D}_{8}\right)$ gave an effective magnetic moment ( $\left.\mu_{\text {eff }}\right)$ of 2.49 $\mu_{\mathrm{B}}$, very close to the theoretical value of $2.54 \mu_{\mathrm{B}}$ for an $\mathrm{f}^{1}$ system (see below for further details and SQUID magnetometry).

When the synthesis of (3) was repeated on a larger scale, a second species co-crystallised with (3), and fractional crystallisation produced a small crop of crystals suitable for single crystal X-ray diffraction. The latter revealed the product to be the ${ }^{t} \mathrm{BuNC}$ adduct of (3) $\left[\mathrm{U}\left(\eta^{8}-\mathrm{C}_{8} \mathrm{H}_{6}\left\{1,4-\mathrm{Si}^{\mathrm{i}} \mathrm{Pr}_{3}\right\}_{2}\right)\left(\eta^{5}-\mathrm{Cp} *\right)\right.$ $\left.\mathrm{O}\left(\eta^{1}-\mathrm{CN}^{t} \mathrm{Bu}\right)\right](4)$, and the molecular structure is shown in Fig. 2.

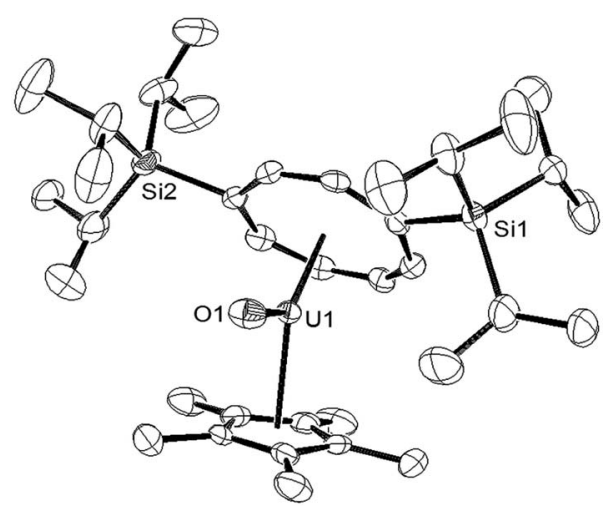

Fig. 1 ORTEP-3 diagram of the molecular structure of (3) displaying $50 \%$ probability ellipsoids. $\mathrm{H}$ atoms have been omitted for clarity. Selected bond-lengths ( $\AA$ ) and angles $\left({ }^{\circ}\right)$ : U1-O1 1.826(3), Ct(COT)-U 1.949(5), Ct(Cp*)-U1 2.492(1); Ct(COT)-U1-Ct(Cp*) 135.27(2), Ct(COT)-U1-O1 162.24(7), Ct(Cp*)-U1-O1 108.08(2).

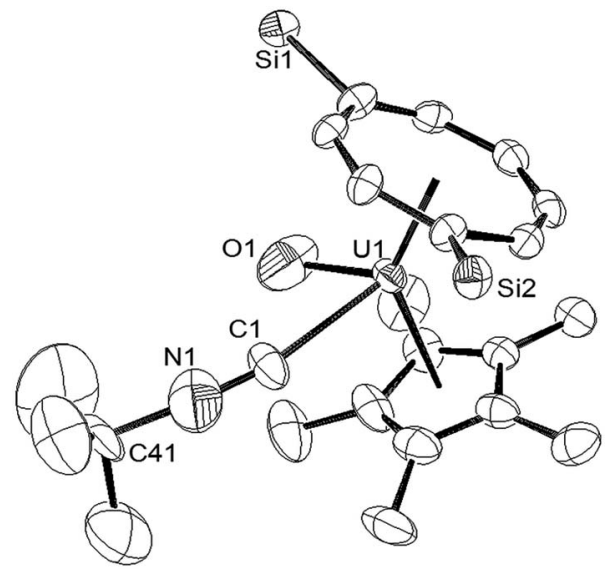

Fig. 2 ORTEP-3 diagram of the molecular structure of (4) displaying $50 \%$ probability ellipsoids. $\mathrm{H}$ atoms and $\operatorname{Pr}$ groups have been omitted for clarity. Selected bond-lengths ( $\AA$ ) and angles ( $\left.{ }^{\circ}\right)$ : U1-C1 2.545(8), C1-N1 1.221(12), U1-O1 1.916(8) C41-N1 1.492(13) Ct(COT)-U1 2.005(2), Ct(Cp*)-U1 2.503(1); N1-C1-U1 162.8(9), C1-N1-C41 169.9(12), O1-U1-C1 71.0(4), Ct(COT)-U1-Ct(Cp*) 137.19(2), Ct(COT)-U1-O1 118.85(2), Ct(Cp*)-U1-O1 95.30(2), Ct(COT)-U1-C1 119.21(8), Ct(Cp*)-U1-C1 94.83(3).

The most salient feature of (4) is the elongation of the $\mathrm{U}-\mathrm{O}$ bond by almost $0.1 \AA$ as compared with that in (3), and also with the $\mathrm{U}^{(\mathrm{V})}=\mathrm{O}$ bonds compared above, with the exception of that in $\left[\mathrm{U}(\mathrm{O})\left(\mathrm{NR}_{2}^{\prime}\right)_{3}\right]\left(\mathrm{R}^{\prime}=\mathrm{SiMe}_{3}\right){ }^{10}$ The reason for this structural feature is unclear, but a possible explanation could be that the isocyanide ligand acts predominantly as a $\sigma$-donor with the extra electron density transferred to $\pi$ symmetry orbitals of the uranium centre involved in antibonding contributions to the $\mathrm{U}-\mathrm{O}$ bond. IR spectroscopy (vide infra) revealed $\nu_{\mathrm{NC}}$ at 2179 $\mathrm{cm}^{-1}$ for the isocyanide ligand in (4), a value very close to those observed in $\left[\mathrm{UCp}_{2}{ }_{2}\left(\mathrm{NMe}_{2}\right)\left({ }^{t} \mathrm{BuNC}_{2}\right] \mathrm{BPh}_{4}\right.$ (ref. 27) and the $\left[\mathrm{UCp}_{3}\left(\mathrm{CNC}_{6} \mathrm{H}_{11}\right)(\mathrm{NCMe})\right]^{+}$cation; ${ }^{28}$ the short $(1.221(12) \AA) \mathrm{CN}$ bond in (4) is also comparable (within esd's) to those in the latter complexes, while the small deviation of the $\mathrm{C}-\mathrm{N}-\mathrm{C}\left({ }^{t} \mathrm{Bu}\right)$ from linearity presumably alleviates steric congestion around the metal centre. The $\mathrm{Ct}(\mathrm{COT})-\mathrm{U} 1-\mathrm{Ct}\left(\mathrm{Cp}^{*}\right)$ angle is slightly more obtuse $\left(c a .2^{\circ}\right)$ than that in (3), while the $\mathrm{Ct}\left(\mathrm{Cp}^{*}\right)-\mathrm{U} 1$ and $\mathrm{Ct}(\mathrm{COT})-\mathrm{U} 1$ distances are slightly elongated but within the range observed for previously reported complexes supported by these ligands.

Attempts to isolate (4) in better yields from the reaction of (1) with ${ }^{t} \mathrm{BuNCO}$ were unsuccessful, leading to mixtures of (3) and (4), and indeed the ${ }^{t} \mathrm{BuNC}$ ligand in (4) is very labile and any attempted isolation or manipulation of (4) via operations in vacuo invariably again led to mixtures of (3) and (4). In order to isolate (3) free from (4), the best route involved the reaction of (1) with ${ }^{t} \mathrm{BuNCO}$ followed by repeated dissolution in pentane and subsequent evaporation, a method used by Andersen and Evans et al. to obtain base-free $\mathrm{Cp}^{*}$ lanthanide complexes, ${ }^{29}$ which afforded (3) in $55 \%$ yield. Reaction of a $\mathrm{C}_{6} \mathrm{D}_{6}$ solution of the resultant microanalytically pure (3) with one equivalent of ${ }^{t}$ BuNC resulted in small but discernible shifts of the resonances due to (3) in the ${ }^{1} \mathrm{H}$-NMR spectrum and which we ascribe to the formation of (4). Similarly, in situ IR spectroscopy showed that, 


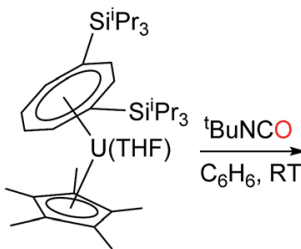

(1)

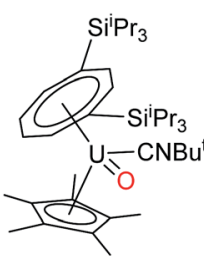

(4)
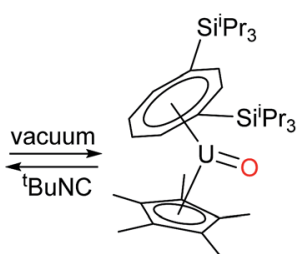

(3)
Scheme 1 Synthesis of terminal oxo U(v) complexes (3) and (4).

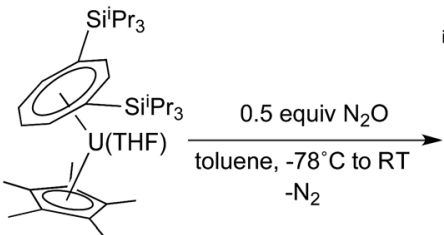

(1)

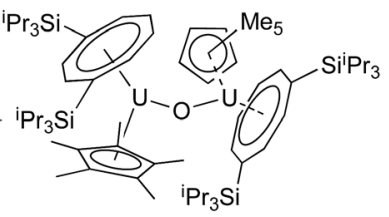

(5)
Scheme 2 Synthesis of (5).

upon reaction of (3) with 1 equivalent of ${ }^{t} \mathrm{BuNC}$ in methylcyclohexane, two new peaks appeared, one at $2134 \mathrm{~cm}^{-1}\left(\nu_{\mathrm{NC}}\right.$ in free ${ }^{t} \mathrm{BuNC}$ ) and one at $2179 \mathrm{~cm}^{-1}$ assigned to $\nu_{\mathrm{NC}}$ in (4).

The above data suggest that the synthesis of the novel $\mathrm{U}(\mathrm{v})$ terminal oxo complex (3) proceeds via the isocyanide adduct (4): the use of ${ }^{t} \mathrm{BuNCO}$ as an efficient oxygen transfer reagent ${ }^{30}$ results in the two electron oxidation of (1) and the formation of ${ }^{t} \mathrm{BuNC}$ and hence (4) (probably via a concerted reaction), and ultimately (3) after work-up (Scheme 1).

We have previously reported the synthesis of the dimeric, $\mu$-oxo U(Iv) complex $\left\{\mathrm{U}\left[\eta^{8}-\mathrm{C}_{8} \mathrm{H}_{6}\left(1,4-\mathrm{Si}^{\mathrm{i}} \mathrm{Pr}_{3}\right)_{2}\right]\left(\eta^{5}-\mathrm{Cp}^{*}\right)\right\}_{2}(\mu-\mathrm{O})(5)$ from the reaction of (1) with a mixture of $\mathrm{NO} / \mathrm{CO}^{31}$ Given the existence of (5), the isolation of the mononuclear terminal oxo $\mathrm{U}(\mathrm{v})$ complex (3) would appear surprising. We therefore decided to investigate whether (3) could be prepared using alternative oxygen transfer reagents. Reaction of (1) with exactly 0.5 equivalents of $\mathrm{N}_{2} \mathrm{O}$ (administered accurately via a Töepler line) in $\mathrm{C}_{7} \mathrm{D}_{8}$ at $-78{ }^{\circ} \mathrm{C}$ resulted in an immediate colour change to bright red, leading to the clean formation of (5) as evidenced by ${ }^{1} \mathrm{H}$ and ${ }^{29} \mathrm{Si}\left\{{ }^{1} \mathrm{H}\right\}$-NMR spectroscopy, and the $\mu$-oxo complex was isolated as the sole product in very good yields (see Scheme 2 and $\operatorname{ESI} \dagger$ ).

On the other hand, when equimolar amounts of $\mathrm{U}(\mathrm{v})$ terminal oxo complex (3) and the U(III) precursor (1) were mixed in $\mathrm{C}_{7} \mathrm{D}_{8}$, no reaction was observed at $\mathrm{RT}$ and conversion to the

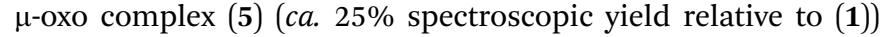
was observed only after heating at $45^{\circ} \mathrm{C}$ over three days. ${ }^{32}$ These experiments in conjunction with the isolation of (4) indicate that these two reactions most likely proceed via different mechanisms. The case of $\mathrm{N}_{2} \mathrm{O}$ would be consistent with a concerted mechanism involving a dinuclear intermediate in which $\mathrm{N}_{2} \mathrm{O}$ bridges, and then eliminates $\mathrm{N}_{2}$ leading to a dinuclear $\mu$-oxo product. However for ${ }^{t} \mathrm{BuNCO}$, the formation of mononuclear (4) after the oxo transfer step, stops any further reaction with (1) that could lead to (5), due to the steric congestion imposed by both the TIPS groups and the ${ }^{t}$ BuNC ligand. To further test this hypothesis, the less sterically hindered homologue of (1), $\left[\mathrm{U}\left\{\eta^{8}-\mathrm{C}_{8} \mathrm{H}_{6}-\left(1,4-\mathrm{SiMe}_{3}\right)_{2}\right\}\left(\eta^{5}-\mathrm{Cp} *\right)\right.$ THF] (2) was reacted with ${ }^{t}$ BuNCO. In this case the reaction furnished cleanly the dinuclear $\mu$-oxo $\mathrm{U}(\mathrm{Iv})$ complex $\left\{\mathrm{U}\left[\eta^{8}\right.\right.$ $\left.\left.\mathrm{C}_{8} \mathrm{H}_{6}\left(1,4-\mathrm{SiMe}_{3}\right)_{2}\right]\left(\eta^{5}-\mathrm{Cp}^{*}\right)\right\}_{2}(\mu-\mathrm{O})(6)$ as evidenced by its NMR spectroscopic data that were in excellent agreement with those previously reported. ${ }^{18 a}$ Compounds (1) and (2) have very similar $\left[\mathrm{U}^{(\mathrm{III})}\right] \leftrightarrow\left[\mathrm{U}^{(\mathrm{IV})}\right]$ redox potentials $\left(-2.13 \mathrm{~V}\right.$ and $-2.10 \mathrm{~V} v s . \mathrm{Fc}^{+/}$ ${ }^{0}$ respectively, see ESI $\dagger$ ), so the clean formation of (6) highlights the importance of the steric hindrance imposed by the silyl substituents on the 8-membered ring in dictating the outcome of the reactions of (1) and (2) with ${ }^{t} \mathrm{BuNCO}$. In the case of (1), reaction with ${ }^{t} \mathrm{BuNCO}$ results in a single $2 \mathrm{e}^{-}$oxidation of the metal centre leading to the U(v) complex (4), and hence (3), whereas in the case of (2) this reaction results in two $1 \mathrm{e}^{-}$ oxidations leading to the dinuclear $\mathrm{U}(\mathrm{Iv})-\mathrm{U}(\mathrm{Iv})$ complex (6) (Scheme 3).

Attempts to generate (3) using other isocyanates (PhNCO, $\left.{ }^{\mathrm{i}} \mathrm{PrNCO}\right)$ or oxo transfer reagents $\left(\mathrm{Me}_{3} \mathrm{NO}\right.$, pyridine $\mathrm{N}$-oxide) were uniformly unsuccessful leading to intractable reaction mixtures. Interestingly when $\mathrm{Me}_{3} \mathrm{SiNCO}$ was reacted with (1), the U(rv) complex $\left\{\mathrm{U}\left[\eta^{8}-\mathrm{C}_{8} \mathrm{H}_{6}\left(1,4-\mathrm{Si}\left({ }^{\mathrm{i}} \mathrm{Pr}\right)_{3}\right)_{2}\right]\left(\eta^{5}-\mathrm{Cp}^{*}\right)\left(\mathrm{OSiMe}_{3}\right)\right\}(7)$ was isolated as the sole product of the reaction. ${ }^{33}$ The isolation of (7) can reasonably be explained by the formation of a shortlived $\left[\mathrm{U}^{(\mathrm{V})}=\mathrm{O}\right]$ complex which, due to the oxophilicity of the $\mathrm{SiMe}_{3}$ group, undergoes a formal reduction to produce the observed U(Iv) complex (7) and presumably cyanogen $(\mathrm{CN})_{2}$ (although formation of the latter was not confirmed). Similar reactivity of $\mathrm{U}=\mathrm{O}$ bonds towards silicon electrophiles has been observed by Andersen $e t a l^{8 a}$

Given the similarities between nitride and oxo ligands, ${ }^{14}$ the successful isolation of the terminal oxo complex (3) suggested that the steric protection afforded by the $\mathrm{U}\left[\eta^{8}-\mathrm{C}_{8} \mathrm{H}_{6}(1,4-\right.$ $\left.\left.\mathrm{Si}^{\mathrm{i}} \mathrm{Pr}_{3}\right)_{2}\right]\left(\eta^{5}-\mathrm{Cp}^{*}\right)$ mixed sandwich framework might be exploited to access the analogous uranium nitride. The highly reducing

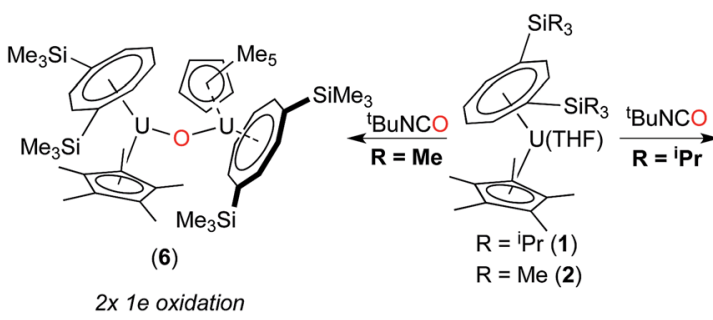

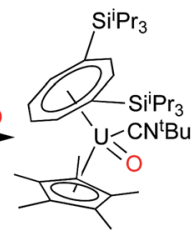

(4)

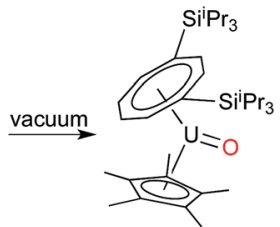

(3)

$1 \times 2 e$ oxidation

Scheme 3 Steric control of the oxidation state of the $U$ centre. 


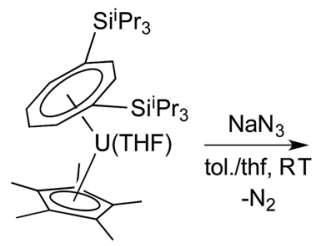

(1)

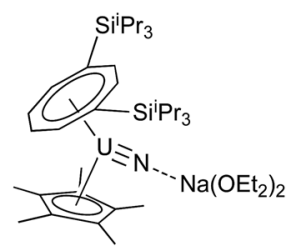

(9)
Scheme 4 Synthesis of (9).

nature of $(\mathbf{1})\left(\mathrm{U}^{\mathrm{III}} / \mathrm{U}^{\mathrm{IV}}-2.13 \mathrm{~V} v s . \mathrm{Fc}^{+/ 0}\right)$, suggested reduction of $\mathrm{N}_{3}{ }^{-}$as a possible method for installing the nitride ligand. ${ }^{13 a}$

Reaction of (1) with $\mathrm{NaN}_{3}$ (Scheme 4) in a mixture of $\mathrm{C}_{7} \mathrm{H}_{8} /$ $\mathrm{C}_{4} \mathrm{H}_{8} \mathrm{O}$ resulted in a slow colour change to brown-red and after work-up and re-crystallisation from $\mathrm{Et}_{2} \mathrm{O}$, brown crystals of (9) were isolated in moderate yield ( $\mathrm{ca} .30 \%$ ), together with other product(s) which could not be unambiguously characterised despite repeated attempts. X-ray diffraction studies showed (9) to be the nitride complex $\left[\mathrm{U}\left\{\eta^{8}-\mathrm{C}_{8} \mathrm{H}_{6}-\left(1,4-\mathrm{Si}^{\mathrm{i}} \mathrm{Pr}_{3}\right)_{2}\right\}\left(\eta^{5}-\mathrm{Cp} *\right)(\mu-\right.$ $\left.\mathrm{N})\left(\mu-\mathrm{Na}\left\{\mathrm{OEt}_{2}\right\}_{2}\right)\right]$, best described as a sodium uranium nitride contact ion pair (Fig. 3).

Liddle et al. recently described a $\mathrm{U}(\mathrm{v})$ terminal nitride anion supported by the TREN ${ }^{\text {TIPS }}$ ligand, as well as its $\mathrm{U}(\mathrm{vI})$ neutral analogue. ${ }^{13 a, b}$ The U-N bond length of 1.835(5) $\AA$ in (9) is comparable to that in the $\mathrm{U}(\mathrm{v})$ nitride complex [U(TREN $\left.{ }^{\mathrm{TIPS}}\right)$ $\mathrm{N}]^{-}\left[\mathrm{Na}(12-\mathrm{c}-4)_{2}\right]^{+}(1.825(15) \AA)$ where the two ions are separated, but is shorter than the one found in $\left[\mathrm{U}\left(\mathrm{TREN}^{\mathrm{TIPS}}\right)(\mu-\mathrm{N})(\mu-\mathrm{Na})\right]_{2}$ (1.883(4) $\AA$ ) where a N-Na interaction is also present. ${ }^{13 a}$ It is also shorter than those in the borane capped nitrido complexes $\left[\left(\mathrm{C}_{6} \mathrm{~F}_{5}\right)_{3} \mathrm{BNU}^{(\mathrm{V})}\left(\mathrm{NMes}{ }^{t} \mathrm{Bu}\right)_{3}\right]\left[\mathrm{N}^{n} \mathrm{Bu}\right](1.916(4) \quad \AA)$ and $\left[\left(\mathrm{C}_{6} \mathrm{~F}_{5}\right)_{3^{-}}\right.$$\left.\mathrm{BNU}^{(\mathrm{VI})}\left(\mathrm{NMes}^{t} \mathrm{Bu}\right)_{3}\right](1.880(4) \AA)^{34}$ (although the latter two can viewed as borane-imido complexes and the bond distances are more typical of $U$ imido complexes). Compared to the neutral $\mathrm{U}(\mathrm{VI})$ complex $\left[\mathrm{U}\left(\mathrm{TREN}^{\mathrm{TIPS}}\right) \mathrm{N}\right]$ the $\mathrm{U}-\mathrm{N}$ bond in (9) is similar within esd's. ${ }^{13 b}$ The Na-N bond length of 2.244(6) $\AA$ in (9) is shorter than the ones found in $\left[\mathrm{U}\left(\mathrm{TREN}^{\mathrm{TIPS}}\right)(\mu-\mathrm{N})(\mu-\mathrm{Na})\right]_{2}$ $(2.308(5) \AA)^{13 a}$ and $\left[\mathrm{U}\left(\mathrm{TREN}^{\mathrm{TIPS}}\right)(\mu-\mathrm{N})(\mu-\mathrm{Na}\{15-\mathrm{c}-5\})\right](2.291(5)$ $\AA),{ }^{13 b}$ and the U-N-Na linkage is close to linear as in the latter.

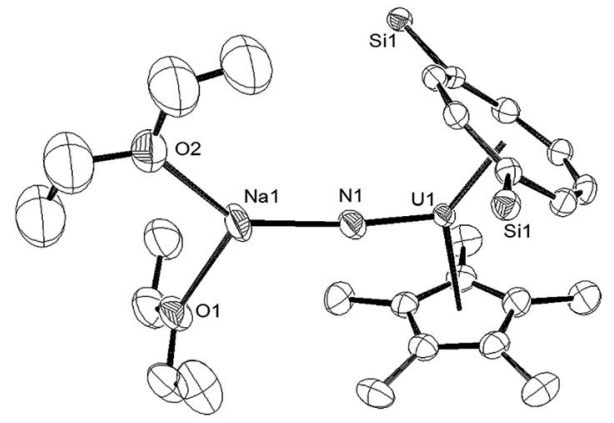

Fig. 3 Ortep-3 diagram of the molecular structure of (9) displaying $50 \%$ probability ellipsoids. $\mathrm{H}$ atoms and ${ }^{\mathrm{i}} \mathrm{Pr}$ groups have been removed for clarity. Selected bond-lengths ( $\AA$ ) and angles $\left({ }^{\circ}\right)$ : U1-N1 1.835(5), $\mathrm{N} 1-\mathrm{Na} 12.244(6), \mathrm{Ct}(\mathrm{COT})-\mathrm{U} 12.026(1), \mathrm{Ct}(\mathrm{Cp} *)-\mathrm{U} 12.548(8) ; \mathrm{U1}-\mathrm{N} 1-$ Na1 172.4(3), Ct(COT)-U1-Ct(Cp*) 137.25(7), Ct(COT)-U1-N1 124.73(5), Ct(Cp*)-U1-N1 101.99(1).
The $\mathrm{Ct}\left(\mathrm{Cp}^{*}\right)-\mathrm{U}$ distance in (9) is elongated compared to (3) and (4) while the $\mathrm{Ct}(\mathrm{COT})-\mathrm{U} 1-\mathrm{N} 1$ and $\mathrm{Ct}\left(\mathrm{Cp}^{*}\right)-\mathrm{U} 1-\mathrm{N} 1$ angles are significantly more acute than the ones found for the corresponding angles Ct-U1-O1 angles in (3). The reason for these differences is unclear.

Complex (9) was further characterised by spectroscopic ${ }^{35}$ and analytical techniques (see ESI $\dagger$ ), and the $\mu_{\text {eff }}$ (Evans method) was determined to be $2.21 \mu_{\mathrm{B}}$ (further details below, including SQUID magnetometry), which is in reasonable agreement with the value of $1.99 \mu_{\mathrm{B}}$ for $\left[\mathrm{U}\left(\mathrm{TREN}^{\mathrm{TIPS}}\right) \mathrm{N}\right]^{-},{ }^{13 a}$ and is within the range of values reported for other $\mathrm{U}(\mathrm{v})$ complexes. ${ }^{36}$

The ${ }^{23} \mathrm{Na}$ NMR spectrum of $(9)$ in THF revealed a single, very broad $\left(\Delta \nu_{1 / 2}=8300 \mathrm{~Hz}\right)$ resonance centred at $c a . \delta 200 \mathrm{ppm}$ suggesting that the interaction of the sodium cation with the paramagnetic uranium centre is maintained in solution ( $c f$. (10), vide infra).

Since the less sterically hindered U(III) complex $\left[\mathrm{U}\left\{\eta^{8}-\mathrm{C}_{8} \mathrm{H}_{6}\right.\right.$ $\left.\left(1,4-\mathrm{SiMe}_{3}\right)_{2}\right\}\left(\eta^{5}-\mathrm{Cp} \mathrm{P}^{*} \mathrm{THF}\right]$ (2) affords the bridging $\mu$-oxo complex (6), the reaction of (2) with a slight excess of $\mathrm{NaN}_{3}(1.5$ mol eq.) in a $\mathrm{C}_{7} \mathrm{H}_{8} / \mathrm{THF}$ solvent mixture (ca. $2: 1$ ) was explored. Indeed, after work-up and re-crystallisation from $\mathrm{THF} / \mathrm{Et}_{2} \mathrm{O}$, brown-red crystals of the bridging nitride complex $\left[\left\{\mathrm{U}\left[\eta^{8}-\right.\right.\right.$ $\left.\left.\left.\mathrm{C}_{8} \mathrm{H}_{6}\left(1,4-\mathrm{SiMe}_{3}\right)_{2}\right]\left(\eta^{5}-\mathrm{Cp}^{*}\right)\right\}_{2}(\mu-\mathrm{N})\right]^{-}\left[\mathrm{Na}(\mathrm{THF})_{6}\right]^{+}$(10) suitable for $\mathrm{X}$-ray diffraction studies were isolated in $81 \%$ yield (Scheme 5 and Fig. 4).

The two U-N bond lengths (N1-U1 2.063(5) $\mathrm{A}$, U2-N1 2.066(5) $\AA$ ) in the anionic dimer are essentially the same, suggesting a delocalised $[\mathrm{U} \simeq \mathrm{N} \simeq \mathrm{U}$ ] bonding interaction as in $\left[\mathrm{Cp}_{2}{ }_{2} \mathrm{U}(\mu-\mathrm{N})\left(\mu-\mathrm{N}_{3}\right) \mathrm{UCp}^{*}{ }_{2}\right]_{4},{ }^{15 e}$ and also the same within esd's to the ones previously reported for other bridging nitride complexes with the exception of the triply bridging nitride in $\left.\left[\left\{\mathrm{UCp}_{2}{ }_{2}(\mu-\mathrm{I})_{2}\right\}_{3}\left(\mu_{3}-\mathrm{N}\right)\right](2.152(3)-2.138(3) \AA)^{1}\right) .{ }^{15 d}$ Furthermore the length of the bond is in the middle of the range found for complexes with localised $\mathrm{U}-\mathrm{N}=\mathrm{U}$ bonding interactions (1.95$2.12 \AA) .{ }^{15 b, c}$ Compared to the U-N bond length in (9), that in (10) is significantly elongated as expected. The $\mathrm{U}-\mathrm{N}-\mathrm{U}$ bond in (10) has significantly deviated from linearity, which is a common structural motif for many bridging $U$ nitride complexes ${ }^{15,37}$ but is less obtuse than those in the $\left[\mathrm{U}^{(\mathrm{IV})}-\mathrm{N}-\mathrm{U}^{(\mathrm{IV})}\right]^{-},\left[\mathrm{U}^{(\mathrm{IV})}-\mathrm{N}-\mathrm{U}^{(\mathrm{V})}\right]$ and $\left[\mathrm{U}^{(\mathrm{IV})}-\mathrm{N}-\mathrm{U}^{(\mathrm{VI})}(\mathrm{O})\right]^{-}$complexes supported by bulky silyl amide ligands,${ }^{15 c}$ that in $\left[\mathrm{KU}(\mu-\mathrm{N})\left(\mathrm{OSi}\left(\mathrm{O}^{t} \mathrm{Bu}\right)_{3}\right)\right]_{2}\left(106.1(2)^{\circ}\right),{ }^{15 b}$ as well as in complexes where the nitride ligand bridges more than two U centre. ${ }^{15 a, d, f}$ Unsurprisingly, the U-N-U bond angle in (10) is identical to the $\mathrm{U}-\mathrm{O}-\mathrm{U}$ bond angle found in the $\mu$-oxo complex $\left\{\mathrm{U}\left[\eta^{8}-\mathrm{C}_{8} \mathrm{H}_{6}\left(1,4-\mathrm{SiMe}_{3}\right)_{2}\right]\left(\eta^{5}-\mathrm{Cp}^{*}\right)\right\}_{2}(\mu-\mathrm{O})(6)^{18 a}$ - a fact that reflects the effect of the sterically imposed geometry of the

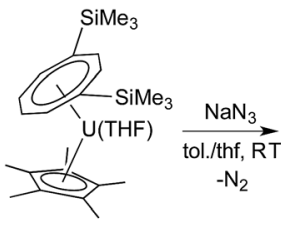

(2)

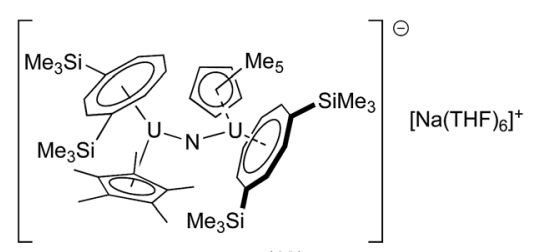

(10)
Scheme 5 Synthesis of (10). 


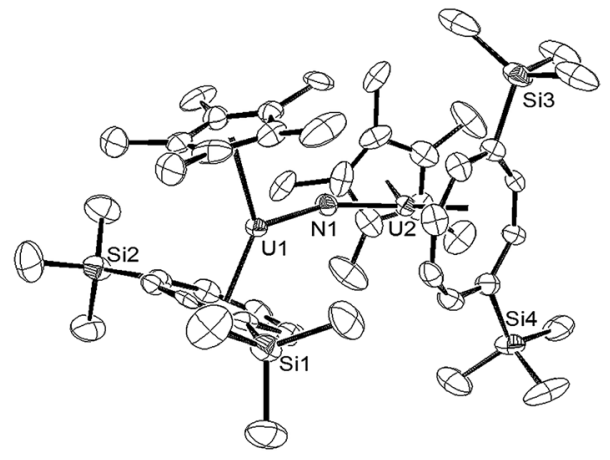

Fig. 4 ORTEP-3 diagram of the molecular structure of the anion in (10) displaying $50 \%$ probability ellipsoids. $\mathrm{H}$ atoms have been removed for clarity. Selected bond-lengths ( $(\AA)$ and angles $\left({ }^{\circ}\right)$ : N1-U1 2.063(5), U2-N1 2.066(5), Ct(COT)-U1 2.033(4), Ct(Cp*)-U1 2.516(2), Ct(COT)-U2 2.038(4), Ct(Cp*)-U2 2.536(2); U1-N1-U2 159.4(3), $\mathrm{Ct}(\mathrm{COT})-\mathrm{U} 1-\mathrm{Ct}(\mathrm{Cp} *)$ 137.03(2), $\mathrm{Ct}(\mathrm{COT})-\mathrm{U} 2-\mathrm{Ct}(\mathrm{Cp} *)$ 136.70(2), Ct(COT)-U1-N1 122.83(8), Ct(Cp*)-U1-N1 100.09(1), Ct(COT)-U2N1 122.75(3), Ct(Cp*)-U2-N1 100.54(2).

Table $1 \mu_{\text {eff }}$ of (3), (9) and (10') at $300 \mathrm{~K}$ in solution and the solid state

\begin{tabular}{lll}
\hline Complex & $\mu_{\text {eff }}$ Evans $\left(\mu_{\mathrm{B}}\right)$ & $\mu_{\text {eff }} \operatorname{SQUID}\left(\mu_{\mathrm{B}}\right)$ \\
\hline$(3)$ & 2.49 & 2.16 \\
$(\mathbf{9})$ & 2.2 & 2.00 \\
$\left(\mathbf{1 0}^{\prime}\right)$ & $3.64(2.57$ per $\mathrm{U})$ & $3.58(2.53$ per $\mathrm{U})$
\end{tabular}

complex. As expected the U-N bonds are shorter than the corresponding $\mathrm{U}-\mathrm{O}$ ones in (6) and that shortening might account for the slightly more acute $\mathrm{Ct}(\mathrm{COT})-\mathrm{U}-\mathrm{Ct}\left(\mathrm{Cp}^{*}\right)$ angles in (10) compared to the ones found in $(6)\left(139.7(16)^{\circ}\right.$ and $\left.140.0(16)^{\circ}\right) .^{18 a}$

Complex (10) readily loses its crystallinity due to loss of coordinated THF to yield $\left[\left\{\mathrm{U}\left[\eta^{8}-\mathrm{C}_{8} \mathrm{H}_{6}\left(1,4-\mathrm{SiMe}_{3}\right)_{2}\right]\left(\eta^{5}-\mathrm{Cp}^{*}\right)\right\}_{2}(\mu-\right.$ $\mathrm{N})]^{-}\left[\mathrm{Na}(\mathrm{THF})_{2}\right]^{+}\left(\mathbf{1 0}^{\prime}\right)$ as a well-defined product, as evidenced by microanalysis. As in the case of its $\mu$-oxo analogue $\left[\left\{\mathrm{U}\left[\eta^{8}\right.\right.\right.$ $\left.\left.\left.\mathrm{C}_{8} \mathrm{H}_{6}\left(1,4-\mathrm{SiMe}_{3}\right)_{2}\right]\left(\eta^{5}-\mathrm{Cp} *\right)\right\}_{2}(\mu-\mathrm{O})\right]$ (6), the ${ }^{1} \mathrm{H}-\mathrm{NMR}\left(\mathrm{C}_{4} \mathrm{D}_{8} \mathrm{O}_{2}\right)$ spectrum of $\left(\mathbf{1 0}^{\prime}\right)$ is consistent with a $C_{2}$-symmetric structure that is retained in solution. In marked contrast to (9), the ${ }^{23} \mathrm{Na}$ NMR spectrum of (10) in THF exhibited a sharp resonance
$\left(\Delta \nu_{1 / 2}=78 \mathrm{~Hz}\right)$ at $\delta-7.94 \mathrm{ppm}$, parameters suggesting no interaction of the $\left[\mathrm{Na}(\mathrm{THF})_{6}\right]^{+}$counterion with the paramagnetic uranium anion. ${ }^{38}$

Similarly to the reaction of (2) with ${ }^{t} \mathrm{BuNCO}$ that yields the $\mu$ oxo complex (6), the bridging nitride complex (10) can be seen as the product of two 1e oxidations of the U(III) precursor ( $v s$. the one 2e oxidation that produces (9) in the case of the bulkier COT substituents), since the formal oxidation state of the uranium centres in (10) is +4 . The $\mu_{\text {eff }}$ for $\mathbf{1 0}^{\prime}\left(\mathrm{C}_{4} \mathrm{D}_{8} \mathrm{O}_{2}\right.$, Evans method) was determined to be $3.64 \mu_{\mathrm{B}}$ for the dimer or $2.57 \mu_{\mathrm{B}}$ per uranium centre, a value consistent with a $\mathrm{U}(\mathrm{Iv})$ ion (further details including SQUID magnetometry below).

\section{Magnetic studies on (3), (9) and (10')}

Table 1 compares the $\mu_{\text {eff }}$ for complexes (3), (9) and (10') at $300 \mathrm{~K}$ as determined in solution (Evans method), and in the solid state (SQUID under an applied field of 0.1 tesla); the values determined by these two methods are in fair agreement.

The effective magnetic moment of (3) exhibits a steady decline from the value of $2.16 \mu_{\mathrm{B}}$ at $300 \mathrm{~K}$ to $1.54 \mu_{\mathrm{B}}$ at $5 \mathrm{~K}$ (Fig. 5). This behaviour is typical for a ${ }^{2} \mathrm{~F}_{5 / 2}$ ion, and is comparable to values reported for molecular $\mathrm{U}(\mathrm{v})$ terminal oxo complexes (see ESI $\dagger$ for plots of $\chi_{\mathrm{m}} / T, \chi_{\mathrm{m}} T / T$ and $\chi_{\mathrm{m}}{ }^{-1} / T$ ). ${ }^{40,22,23}$

In the case of the nitride complex (9), its effective magnetic moment was found to be $2.00 \mu_{\mathrm{B}}$ at $300 \mathrm{~K}$ and $1.35 \mu_{\mathrm{B}}$ at $5 \mathrm{~K}$ (Fig. 5). These values are comparable to the effective magnetic moment found for nitride complex [UN(TREN $\left.\left.{ }^{\mathrm{TIPS}}\right)\right][\mathrm{Na}(12-$ crown-4) $)_{2}$ ( $\left(1.99 \mu_{\mathrm{B}}\right.$ at $298 \mathrm{~K}, 1.31 \mu_{\mathrm{B}}$ at $\left.1.8 \mathrm{~K}\right),{ }^{13 a}$ and are in agreement with literature values for molecular $\mathrm{U}(\mathrm{v})$ complexes more generally ${ }^{39}$ (see ESI $\dagger$ for plots of $\chi_{\mathrm{m}} / T, \chi_{\mathrm{m}} T / T$ and $\chi_{\mathrm{m}}{ }^{-1} / T$ ).

Magnetic susceptibility data sets for $\left(\mathbf{1 0}^{\prime}\right)$ measured for zerofield cooled and field cooled samples coincided exactly, indicating the absence of long-range interactions between spins on the two U(Iv) centres. At $300 \mathrm{~K}$ the effective magnetic moment per $\mathrm{U}$ is $2.53 \mu_{\mathrm{B}}$, and decreases to $0.69 \mu_{\mathrm{B}}$ at $2 \mathrm{~K}$ (Fig. 6a), consistent with two $\mathrm{U}^{\mathrm{IV}} \mathrm{f}^{2}$ ions. For comparison, the solid state magnetic studies on the di-uranium(Iv) dianion $\left[\left\{\left({ }^{\left({ }^{\mathrm{P}}, \mathrm{Me}\right.} \mathrm{ArO}\right)_{3^{-}}\right.\right.$ tacn) $\left.\mathrm{U}\}_{2}(\mu-\mathrm{O})_{2}\right]^{2-}$ by Meyer et al. showed a $\mu_{\text {eff }}$ per $\mathrm{U}$ of $2.73 \mu_{\mathrm{B}}$ at $300 \mathrm{~K}^{40}$ The majority of paramagnetic substances have a molar susceptibility $\left(\chi_{\mathrm{m}}\right)$ that obeys the Curie-Weiss law,
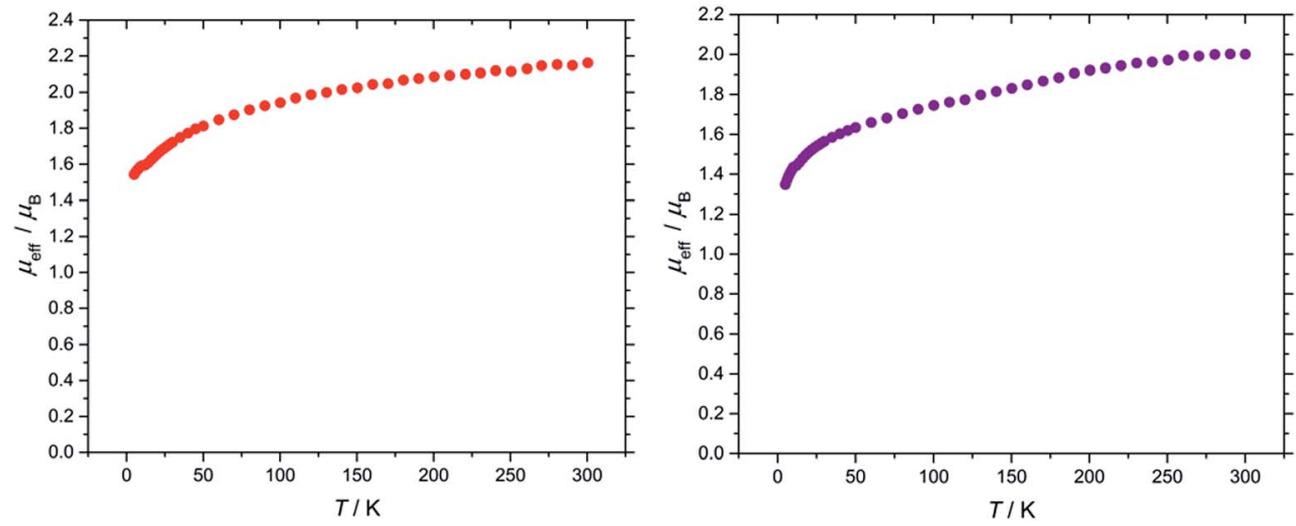

Fig. 5 Temperature dependence of the solid state $\mu_{\text {eff }}$ of (3) (left) and (9) (right) at 0.1 tesla. 

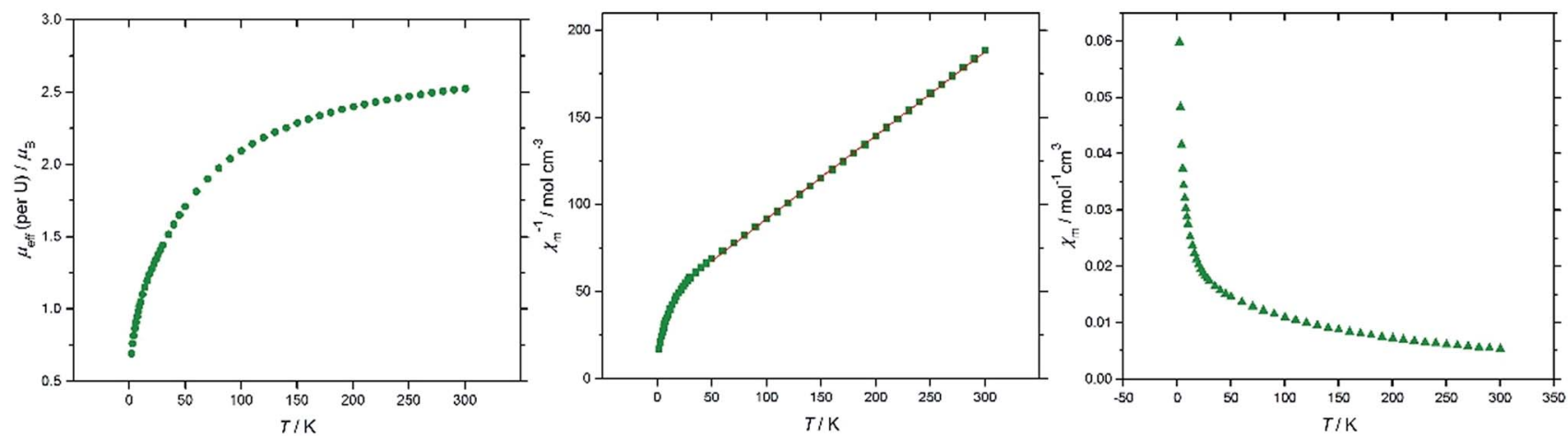

Fig. 6 Magnetic data for $\left(10^{\prime}\right)$. From left to right: $\mu_{\text {eff }}$ (per U) $/ T ; \chi_{\mathrm{m}}{ }^{-1} / T$ (red line is a linear fit to the data in the range $50-300 \mathrm{~K}$ ); $\chi_{\mathrm{m}} / T($ see $\mathrm{ESI} \dagger$ for the plot of $\chi_{m} T / T$.

$\chi_{\mathrm{m}}=C /(T-\Theta)$, where $C$ is the Curie constant and $\Theta$ is the Weiss constant. The plot of $\chi_{\mathrm{m}}{ }^{-1}$ vs. $T$ (Fig. $6 \mathrm{~b}$ ) follows CurieWeiss behavior in the range $50-300 \mathrm{~K}$, with $C=0.0289 \mathrm{~K}^{-1}$ $\mathrm{mol}^{-1}$ and $\Theta=-0.015 \mathrm{~K}$, suggesting that at these temperatures the $\left[\left\{\mathrm{U}\left[\eta^{8}-\mathrm{C}_{8} \mathrm{H}_{6}\left(1,4-\mathrm{SiMe}_{3}\right)_{2}\right]\left(\eta^{5}-\mathrm{Cp}^{*}\right)\right\}_{2}(\mu-\mathrm{N})\right]^{-}$anion behaves as two non-interacting $\mathrm{U}^{(\mathrm{IV})}$ centres. Furthermore, there is no maximum observed in the $\chi_{\mathrm{m}} v s$. $T$ plot (Fig. $6 \mathrm{c}$ ), often cited as a definitive indication of antiferromagnetic coupling. The $\mathrm{U}^{(\mathrm{IV})}$ ion $\left({ }^{3} \mathrm{H}_{4}\right.$ ground term) typically has minimal covalency, hence the two metal centres in $\mathbf{1 0}^{\prime}$ do not participate in exchange coupling.

Finally, magnetic data for all three compounds (3), (9) and $\left(\mathbf{1 0}^{\prime}\right)$ are presented in Fig. 7 for comparison.

\section{Redox behaviour of (3), (9) and (10)}

In order to gauge the potential for accessing terminal oxo and nitrido uranium(vI) complexes, the redox properties of (3), (9) and (10) were studied by cyclic voltammetry (C.V.).

In contrast to the terminal oxo $\left[\left(\left(^{t \mathrm{Bu}} \mathrm{ArO}\right) \operatorname{tacn}\right) \mathrm{U}(\mathrm{O})\right]$ complex reported by Meyer et al. that features a reversible oxidation, ${ }^{4 o}$

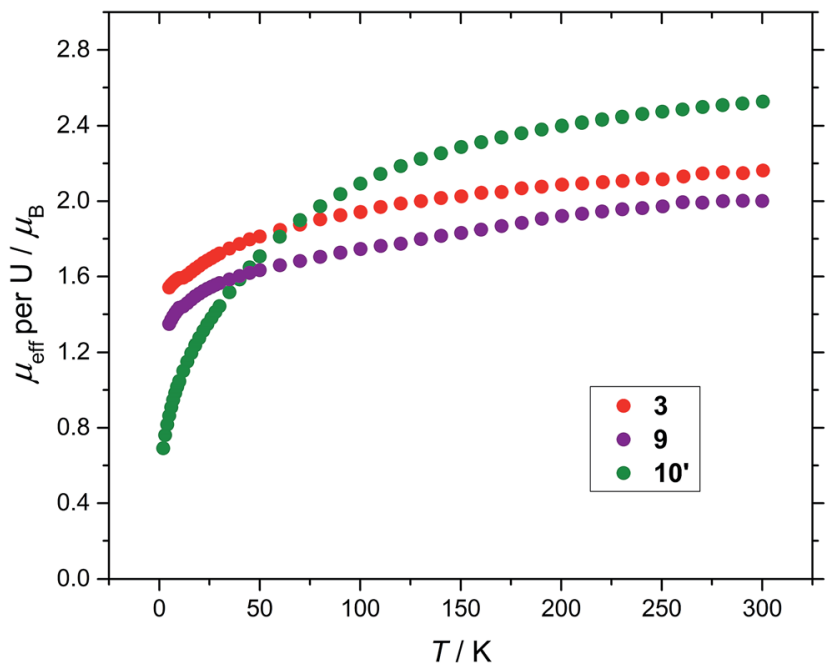

Fig. 7 Temperature dependence of the solid state $\mu_{\text {eff }}$ of (3), (9) and $\left(10^{\prime}\right)$ (per U) at 0.1 tesla. the C.V. of the terminal oxo complex (3) revealed only a quasireversible reduction process at $-1.77 \mathrm{~V} v s$. $\mathrm{Fc}^{+/ 0}$ (Fig. 8).

Changing the scan rate $\left(50-300 \mathrm{mV} \mathrm{s}^{-1}\right)$ did not alter the shape of the observed wave and no other processes were found to occur over the solvent window. This process is assigned to the $\left[\mathrm{U}^{(\mathrm{V})}\right] \leftrightarrow\left[\mathrm{U}^{(\mathrm{IV})}\right]$ couple, and based on this voltammogram, the reduction of (3) should be a chemically accessible process. Indeed, (3) can be chemically reduced with a slight excess of $\mathrm{K} /$ $\mathrm{Hg}(0.5 \% \mathrm{w} / \mathrm{w})$ in the presence of 18 -crown- 6 in $n$-pentane $/ \mathrm{Et}_{2} \mathrm{O}$. The almost instantaneous reaction produced a red-pink solid that, after work-up and re-crystallisation from toluene, gave dark red rods suitable for X-ray diffraction studies which showed the product to be the U(Iv) complex $\left[\mathrm{U}\left\{\eta^{8}-\mathrm{C}_{8} \mathrm{H}_{6}-(1,4-\right.\right.$ $\left.\left.\left.\mathrm{Si}^{\mathrm{i}} \mathrm{Pr}_{3}\right)_{2}\right\}\left(\eta^{5}-\mathrm{Cp}{ }^{*}\right)(\mu-\mathrm{O}) \mathrm{K}(18-\mathrm{c}-6)\right]$ (11) (Fig. 9).

The U-O bond length (1.891(4) $\AA$ ) in (11) is longer than that in the $\mathrm{U}(\mathrm{v})$ complexes $(3)(1.826(3) \AA)$ and $\left[\mathrm{U}\left(\mathrm{NR}_{2}{ }^{\prime}\right)_{3} \mathrm{O}\right]^{10}(1.826(3)$ $\AA)$, but similar within esd's to the one found in the U(IV) complex (4) $(1.916(8) \AA)$. The K1-O1 bond length is as expected shorter than the $\mathrm{O}=\mathrm{U}=\mathrm{O} \cdots \mathrm{K}$ bonds $(2.60-2.9 \AA)^{41}$ and is typical of an ionic $\mathrm{K}-\mathrm{O}$ bond; ${ }^{\mathbf{1 2}}$ the $\mathrm{U}-\mathrm{O}-\mathrm{K}$ bond is very close to linear.

Complex (11) was fully characterised by spectroscopic and analytical methods (see ESI $\dagger$ ); the ${ }^{29} \mathrm{Si}\left\{{ }^{1} \mathrm{H}\right\}$-NMR was of particular diagnostic value as it was shifted upfield to $-172.22 \mathrm{ppm}$

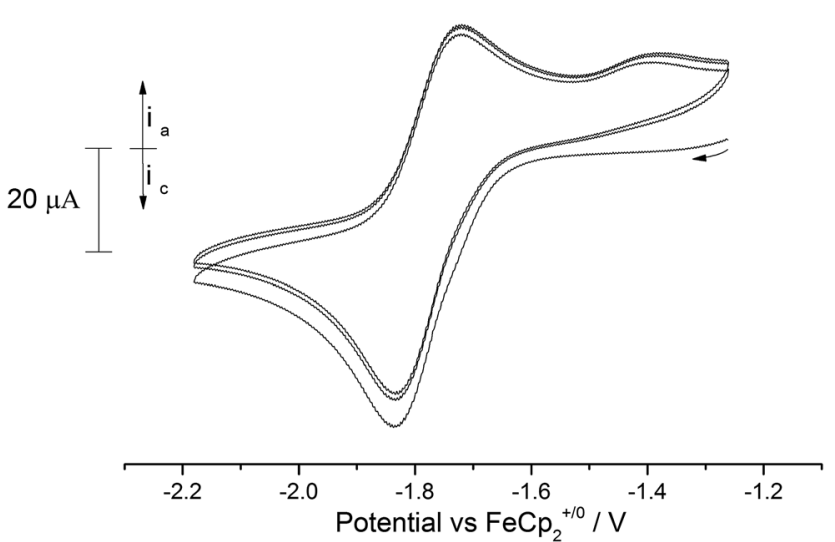

Fig. 8 Overlaid CV scans (3 cycles) of (3) in $0.05 \mathrm{M}\left[\mathrm{N}\left({ }^{n} \mathrm{Bu}\right)_{4}\right]\left[\mathrm{B}\left(\mathrm{C}_{6} \mathrm{~F}_{5}\right)_{4}\right] /$ THF. Scan rate $250 \mathrm{mV} \mathrm{s}^{-1}$. 


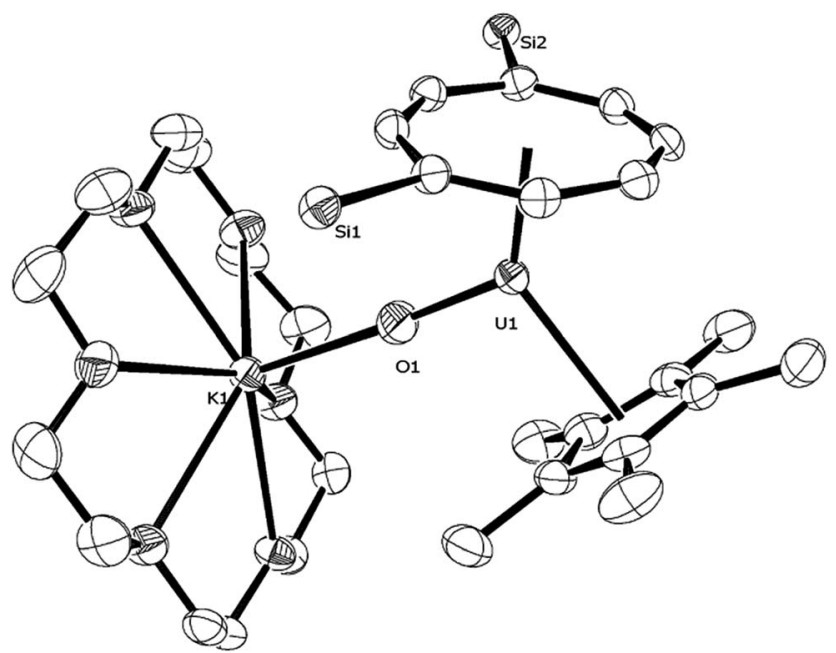

Fig. 9 ORTEP-3 diagram of the molecular structure of (11) displaying $50 \%$ probability ellipsoids. $\mathrm{H}$ atoms, ${ }^{\mathrm{i}} \mathrm{Pr}$ groups and a molecule of toluene have been removed for clarity. Selected bond-lengths $(\AA)$ and angles $\left({ }^{\circ}\right)$ : U1-O1 1.891(4), Ct(COT)-U 2.041(1), Ct(Cp*)-U1 2.583(4), O1-K1 2.582(4); U1-O1-K1 177.3(2), Ct(COT)-U1-Ct(Cp*) 133.81(2), Ct(COT)-U1-O1 125.73(6), Ct(Cp*)-U1-O1 100.45(2).

$(-72.7 \mathrm{ppm}$ for parent (3)), a value that is even more upfield than that for the U(III) complex (1) (-129 ppm), probably due to the anionic nature of (11).

C.V. scans of the nitride complex (9) in the anodic direction over several cycles revealed the existence of several processes in the accessible solvent window (see ESI Fig. SI8 $\dagger$ for a full voltammogram). Of these processes, there is a noteworthy quasireversible oxidation at $-1.63 \mathrm{~V}$ vs. $\mathrm{Fc}^{+/ 0}$ (Fig. 10) which we tentatively assign to the $\left[\mathrm{U}^{(\mathrm{VI})}\right] \leftrightarrow\left[\mathrm{U}^{(\mathrm{V})}\right]$ couple. As can be seen from Fig. 10, a second process at slightly more cathodic potential $\left(c a .-1.8 \mathrm{~V} v s . \mathrm{Fc}^{+/ 0}\right)$ is also present, which features an asymmetric current response that leads us to conclude that this is probably related to a short lived electrochemically generated species. The shape of the wave at $-1.63 \mathrm{~V}$ did not change by variation of the scan rate $\left(50-350 \mathrm{mV} \mathrm{s}^{-1}\right)$.

In addition to this process, the (full) voltammogram of (9) exhibits also another two irreversible processes: one anodic at $0.7 \mathrm{~V}$ and a cathodic one at $-2.8 \mathrm{~V}\left(\right.$ both $\left.v s . \mathrm{Fc}^{+/ 0}\right)$. The nature of
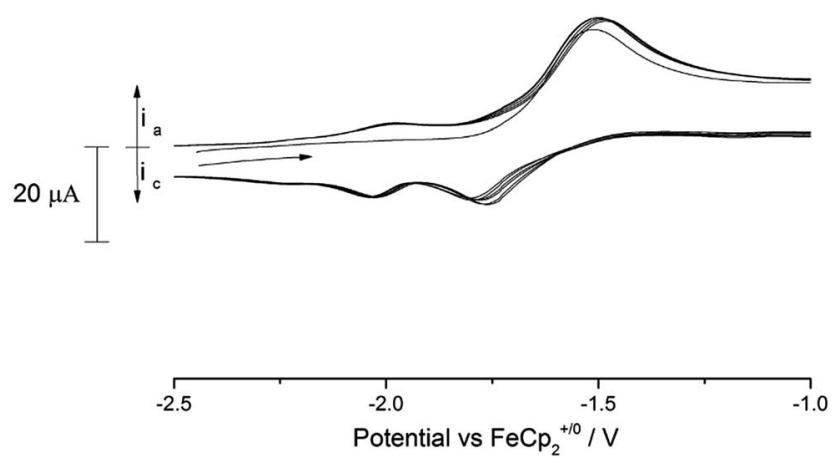

Fig. 10 Overlaid scan (4 cycles) of (9) in $0.05 \mathrm{M}\left[\mathrm{N}\left({ }^{n} \mathrm{Bu}\right)_{4}\right]\left[\mathrm{B}\left(\mathrm{C}_{6} \mathrm{~F}_{5}\right)_{4}\right] /$ THF. Scan rate $100 \mathrm{mV} \mathrm{s}^{-1}$.

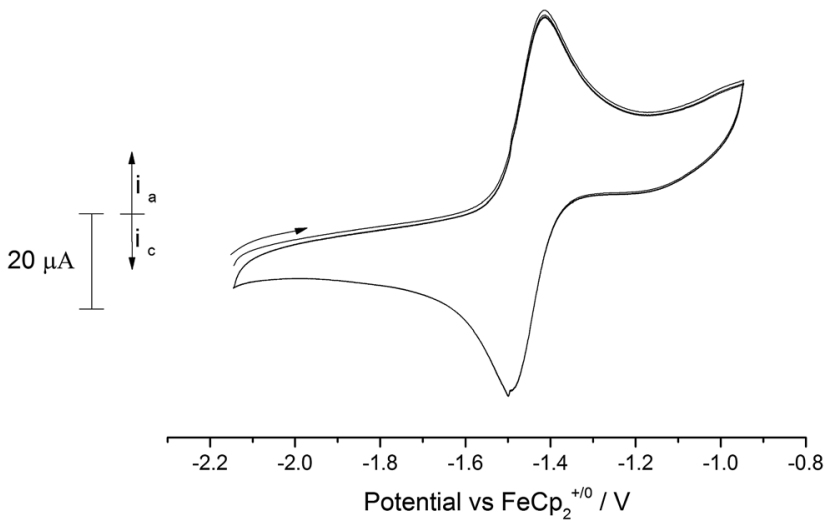

Fig. 11 Overlaid CV scans (2 cycles) of $\left(10^{\prime}\right)$ in $0.1 \mathrm{M}\left[\mathrm{N}\left({ }^{n} \mathrm{Bu}\right)_{4}\right]\left[\mathrm{PF}_{6}\right] /$ acetonitrile. Scan rate $150 \mathrm{mV} \mathrm{s}^{-1}$.

these two irreversible processes cannot be unambiguously assigned, but they could be due to ligand activation involving the nitride moiety. Attempts to chemically oxidise (9) by reaction with mild oxidants such as $\mathrm{I}_{2}$ and $\mathrm{AgBPh}_{4}$ have thus far resulted in intractable mixtures from which only ligand decomposition could be observed spectroscopically ( $\left.{ }^{1} \mathrm{H}-\mathrm{NMR}\right)$.

Similarly, anodic scans of the bridging nitride (10) revealed a quasi-reversible process (peak separation $87 \mathrm{mV}$ ) centred at $-1.46 \mathrm{~V} v$ s. $\mathrm{Fc}^{+/ 0}$ (Fig. 11). This value is very close to the one observed for complex (9) as well as for the $\left\{\left[\mathrm{U}^{(\mathrm{IV})}\right]=\mathrm{N}=\left[\mathrm{U}^{(\mathrm{IVV})}\right]\right\}^{-}$ $\leftrightarrow\left\{\left[\mathrm{U}^{(\mathrm{V})}\right]=\mathrm{N}=\left[\mathrm{U}^{(\mathrm{IV})}\right]\right\}$ couple $\left([\mathrm{U}]=\mathrm{U}\left(\mathrm{NMes}^{t} \mathrm{Bu}\right)_{3}\right)$ reported by Cummins et al. ${ }^{15 f}$ Based on this, we tentatively assign this process to the $\left\{\left[\mathrm{U}^{(\mathrm{IV})}\right]-\mathrm{N}-\left[\mathrm{U}^{(\mathrm{V})}\right]\right\} \leftrightarrow\left\{\left[\mathrm{U}^{(\mathrm{IV})}\right]-\mathrm{N}-\left[\mathrm{U}^{(\mathrm{IV})}\right]\right\}$ redox pair.

Apart from this process, the voltammogram also displayed additional irreversible processes centred at anodic voltages $(-0.5 \mathrm{~V},-0.25 \mathrm{~V}, 0.35 \mathrm{~V}$; see ESI Fig. SI10†) that are probably due to the formation of higher oxidation state (mixed valence) species (i.e. $\left\{\left[\mathrm{U}^{(\mathrm{V})}\right]-\mathrm{N}-\left[\mathrm{U}^{(\mathrm{V})}\right]\right\},\left\{\left[\mathrm{U}^{(\mathrm{VI})}\right]-\mathrm{N}-\left[\mathrm{U}^{(\mathrm{V})}\right]\right\}$ etc.), although other reasons (e.g. ligand activation) cannot be excluded. As in the case of (9) an irreversible reduction is also observed at $c a$. $-2.5 \mathrm{~V} v s . \mathrm{Fc}^{+/ 0}$ that as above could correspond to a mixed valence species (i.e. $\left.\left\{\left[\mathrm{U}^{(\mathrm{III})}\right]-\mathrm{N}-\left[\mathrm{U}^{(\mathrm{V})}\right]\right\}\right)$ or arise from a ligand activation process. Given that similar processes appear in the case of (9), we envisage that they are more likely due to the latter rather than the former.

\section{Conclusion}

In summary we have described how the steric environment around the metal centre can manipulate redox events at a uranium centre. This has been demonstrated by the isolation of either mononuclear $\mathrm{U}(\mathrm{v})$ or dinuclear $\mathrm{U}(\mathrm{rv})$ nitrido/oxo complexes depending on the size of the silyl substituents on the supporting ligands. This has led to the preparation of an anionic uranium(v) nitride complex (9) featuring a U-N triple bond, as well as a neutral U(v) terminal oxo complex (3). Magnetic studies corroborate the formal oxidation states of these complexes further confirming that the $2 \mathrm{e}^{-}$oxidation leads to products featuring either one $\mathrm{U}(\mathrm{v})$ or two $\mathrm{U}(\mathrm{Iv})$ metal centres depending on steric hindrance at the uranium centre. Cyclic 
voltammetry studies of complex (3) show that it can be readily reduced to the $\left[\mathrm{U}^{(\mathrm{IV})}=\mathrm{O}^{-}\right.$anion (11), which has also been achieved chemically. Unlike (3), cyclic voltammetry studies have shown that the nitride complex (9) might be amenable to oxidation to the $\mathrm{U}(\mathrm{vI})$ species although initial attempts to do so have been unsuccessful thus far.

\section{Acknowledgements}

We thank the ERC (Project 247390), the EPSRC (EP/M023885/1) and the University of Sussex for financial support. The UK National Crystallography Service (NCS) Southampton are thanked for their assistance with single crystal X-ray data collection.

\section{References}

1 (a) P. L. Arnold, Chem. Commun., 2011, 47, 9005; (b) T. Andrea and M. S. Eisen, Chem. Soc. Rev., 2008, 37, 550; (c) M. Ephritikine, Organometallics, 2013, 32, 2464; (d) H. S. La Pierre and K. Meyer, Prog. Inorg. Chem., 2014, 58, 303-416; (e) S. T. Liddle, Angew. Chem., Int. Ed., 2015, 54, 8604-8641.

2 (a) Recent Advances in Actinide Science, ed. R Alvarez, N. D. Bryan and I. May, RSC Publishing, 2006; (b) B. M. Gardner and S. T. Liddle, Eur. J. Inorg. Chem., 2013, 22-23, 3753; (c) P. L. Arnold, S. M. Mansell, L. Maron and D. M. McKay, Nat. Chem., 2012, 4, 668-674; (d) B. Kosog, C. Kefalidis, F. W. Heinemann, L. Maron and K. Meyer, J. Am. Chem. Soc., 2012, 134, 12792-12794; (e) I. Castro-Rodríguez and K. Meyer, Chem. Commun., 2006, 1353-1368; (f) P. L. Arnold, M. W. McMullon, J. Rieb and F. E. Kuhn, Angew. Chem., Int. Ed., 2015, 54, 82-100.

3 (a) M. R. MacDonald, M. E. Fieser, J. E. Bates, J. W. Ziller, F. Furche and W. J. Evans, J. Am. Chem. Soc., 2013, 135, 13310; (b) H. S. La Pierre, A. Scheurer, F. W. Heinemann, W. Hieringer and K. Meyer, Angew. Chem., Int. Ed., 2014, 53, 7158.

4 (a) S. G. Minasian, J. L. Krinsky, V. A. Williams and J. Arnold, J. Am. Chem. Soc., 2008, 130, 10086-10087; (b) S. T. Liddle, J. McMaster, D. P. Mills, A. J. Blake, C. Jones and W. D. Woodwul, Angew. Chem., Int. Ed., 2009, 48, 10771080; (c) B. M. Gardner, G. Balázs, M. Scheer, F. Tuna, E. J. L. McInnes, J. McMaster, W. Lewis, A. J. Blake and S. T. Liddle, Nat. Chem., 2015, 7, 582-590; (d) B. M. Gardner, G. Balázs, M. Scheer, A. J. Wooles, F. Tuna, E. J. L. McInnes, J. McMaster, W. Lewis, A. J. Blake and S. T. Liddle, Angew. Chem., Int. Ed., 2015, 54, 15250-15254; (e) B. M. Gardner, G. Balázs, M. Scheer, F. Tuna, E. J. L. McInnes, J. McMaster, W. Lewis, A. J. Blake and S. T. Liddle, Angew. Chem., Int. Ed., 2014, 53, 4484-4488; $(f)$ Q.-Y. Wu, J.-H. Lan, C.-Z. Wang, Y.-L. Zhao, Z.-F. Chai and W.-Q. Shi, J. Phys. Chem. A, 2015, 119, 922-930; $(g)$ S. M. Franke, F. W. Heinemann and K. Meyer, Chem. Sci., 2014, 5, 942-950; (h) T. Cantat, T. Arliguie, A. Noël, P. Thuéry, M. Ephritikhine, P. Le Floch and N. Mézailles, J. Am. Chem. Soc., 2009, 131, 963-972; (i) T. W. Hayton,
J. M. Boncella, B. L. Scott, P. D. Palmer, E. R. Batista and P. J. Hay, Science, 2005, 310, 1941-1943; (j) M. Porchia, F. Ossola, G. Rossetto, P. Zanella and N. Brianese, J. Chem. Soc., Chem. Commun., 1987, 550; (k) G. Paolucci, G. Rossetto, P. Zanella and R. D. Fischer, J. Organomet. Chem., 1985, 284, 213; ( $l$ ) M. Porchia, U. Casellato, F. Ossola, G. Rossetto, P. Zanella and N. Brianese, J. Chem. Soc., Chem. Commun., 1986, 1034; (m) P. L. Diaconescu, A. L. Odom, T. Agapie and C. C. Cummins, Organometallics, 2001, 20, 4993-4995; (n) M. Porchia, N. Brianese, U. Casellato, F. Ossola, G. Rossetto and P. Zanella, J. Chem. Soc., Dalton Trans., 1989, 677-681; (o) S. C. Bart, C. Anthon, F. W. Heinmann, E. Bill, N. M. Edelstein and K. Meyer, J. Am. Chem. Soc., 2008, 130, 12536-12546; (p) I. C. Rodríguez, H. Nakai and K. Meyer, Angew. Chem., Int. Ed., 2006, 25, 2389-2392; (q) C. J. Windorff and W. J. Evans, Organometallics, 2014, 33, 3786-3791; (r) A.-C. Schmidt, F. W. Heinmann, L. Maron and K. Meyer, Inorg. Chem., 2014, 53, 13142-13153; (s) N. H. Anderson, S. O. Odoh, Y. Yao, U. J. Williams, B. A. Schaefer, J. J. Kiernicki, A. J. Lewis, M. D. Goshert, P. E. Fanwick, E. J. Schelter, J. R. Walensky, L. Gagliardi and S. C. Bart, Nat. Chem., 2014, 6, 919-926; $(t)$ P. A. Cleaves, D. M. King, C. E. Kefalidis, L. Maron, F. Tuna, E. J. L. McInes, J. McMaster, W. Lewis, A. J. Blake and S. T. Liddle, Angew. Chem., Int. Ed., 2014, 53, 1041210415; (u) O. P. Lam, F. W. Heinemann and K. Meyer, Chem. Sci., 2011, 2, 1538-1547; (v) J. A. Higgins-Frey, F. G. N. Cloke and S. Mark Roe, Organometallics, 2015, 34, 2102-2105; (w) D. M. King, J. McMaster, F. Tuna, E. J. L. McInes, W. Lewis, A. J. Blake and S. T. Liddle, J. Am. Chem. Soc., 2014, 136, 5619-5622; (x) J. L. Brown, S. Fortier, R. A. Lewis, G. Wu and T. W. Hayton, J. Am. Chem. Soc., 2012, 134, 15468-15475; (y) N. H. Anderson, H. Yin, J. J. Kiernicki, P. E. Fanwick, E. J. Schelter and S. C. Bart, Angew. Chem., Int. Ed., 2015, 54, 9386-9389; (z) J. L. Brown, S. Fortier, G. Wu, N. Katsoyannis and T. W. Hayton, J. Am. Chem. Soc., 2013, 135, 5352-5355.

5 (a) A. E. Commyns, Chem. Rev., 1960, 50, 115; (b) F. H. Allen, Acta Crystallogr., Sect. B: Struct. Sci., 2002, 58, 380; (c) P. L. Arnold, J. B. Love and D. Patel, Coord. Chem. Rev., 2009, 253, 1973-1978; (d) Z. Szabo, T. Toraishi, V. Vallet and I. Grenthe, Coord. Chem. Rev., 2006, 250, 816.

6 (a) P. L. Arnold, G. M. Jones, S. O. Odoh, G. Schreckenbach, N. Magnani and J. B. Love, Nat. Chem., 2012, 4, 221-227; (b) P. L. Arnold, D. Patel, A. J. Blake, C. Wilson and J. B. Love, J. Am. Chem. Soc., 2006, 130, 9610; (c) G. M. Jones, P. L. Arnold and J. B. Love, Angew. Chem., Int. Ed., 2012, 51, 12584-12587.

7 The Chemistry of the Actinide Elements, J. J. Katz, G. T. Seaborg and L. R. Morss, Chapman and Hall, New York, 1986.

8 (a) G. Zi, L. Jia, E. L. Werkema, M. D. Walter, J. P. Gottfriesden and R. A. Andersen, Organometallics, 2005, 24, 4251-4264; (b) O. P. Lam, S. C. Bart, F. W. Heinemann and K. Meyer, Chem. Commun., 2010, 46, 3137.

9 (a) L. R. Avens, D. M. Barnhart, C. J. Burns, S. D. McKee and W. H. Smith, Inorg. Chem., 1994, 33, 4245-4254; (b) S. J. Kraft, 
J. Walensky, P. E. Fanwick, M. B. Hall and S. C. Bart, Inorg. Chem., 2010, 49, 7620-7622; (c) W. J. Evans, S. A. Kozimor and J. W. Ziller, Polyhedron, 2004, 23, 2689-2694; (d) B. M. Gardner, W. Lewis, A. J. Blake and S. T. Liddle, Inorg. Chem., 2011, 50, 9631-9641.

10 S. Fortier, J. L. Brown, N. Kaltsoyannis, G. Wu and T. W. Hayton, Inorg. Chem., 2012, 51, 1625-1633.

11 (a) D. M. King, F. Tuna, J. McMaster, W. Lewis, A. J. Blake, E. J. L. McInnes and S. T. Liddle, Angew. Chem., Int. Ed., 2013, 52, 4921-4924; (b) P. Roussel, R. Boaretto, A. J. Kingsley, N. W. Alcock and P. Scott, J. Chem. Soc., Dalton Trans., 2002, 1423.

12 O. Cooper, C. Camp, J. Pécaut, C. E. Kefalidis, L. Maron, S. Gambarelli and M. Mazzanti, J. Am. Chem. Soc., 2014, 136, 6716-6723.

13 (a) D. M. King, F. Tuna, E. J. L. McInnes, J. McMaster, W. Lewis, A. J. Blake and S. T. Liddle, Science, 2012, 337, 717; (b) M. King, F. Tuna, E. J. L. McInnes, J. McMaster, W. Lewis, A. J. Blake and S. T. Liddle, Nat. Chem., 2013, 5, 482.

14 The Organometallic Chemistry of the Transition Metals, R. H. Crabtree, John Wiley \& Sons, 5th edn, 2009.

15 (a) G. Nocton, J. Pécaut and M. Mazzanti, Angew. Chem., Int. Ed., 2008, 47, 3040-3042; (b) C. Camp, J. Pécaut and M. Mazzanti, J. Am. Chem. Soc., 2013, 135, 12101-12111; (c) S. Fortier, G. $\mathrm{Wu}$ and T. W. Hayton, J. Am. Chem. Soc., 2010, 132, 6888-6889; (d) W. J. Evans, K. A. Miller, J. W. Ziller and J. Greaves, Inorg. Chem., 2007, 46, 8008; (e) W. J. Evans, S. A. Kozimor and J. W. Ziller, Science, 2005, 309, 1835; ( $f$ ) A. R. Fox, P. L. Arnold and C. C. Cummins, J. Am. Chem. Soc., 2010, 132, 3250-3251; (g) L. Chatelain, R. Scopelliti and M. Mazzanti, J. Am. Chem. Soc., 2016, 138, 1784-1787.

16 D. W. Green and G. T. Reedy, J. Chem. Phys., 1976, 65, 2921; R. D. Hunt, J. T. Yustein and L. Andrews, J. Chem. Phys., 1993, 98, 6070; L. Andrews, X. Wang, R. Lindh, B. O. Roos and C. J. Marsden, Angew. Chem., Int. Ed., 2008, 47, 5366.

17 R. K. Thomson, T. Cantat, B. L. Scott, D. E. Morris, E. R. Batista and J. L. Kiplinger, Nat. Chem., 2010, 2, 723-729.

18 (a) N. Tsoureas, L. Castro, A. F. R. Kilpatrick, F. G. N. Cloke and L. Maron, Chem. Sci., 2014, 5, 3777; (b) O. T. Summerscales, A. S. Frey, F. G. N. Cloke and P. B. Hitchcock, Chem. Commun., 2009, 198.

19 (a) O. T. Summerscales, F. G. N. Cloke, P. B. Hitchcock, J. C. Green and N. Hazari, Science, 2006, 311, 829; (b) O. T. Summerscales, F. G. N. Cloke, P. B. Hitchcock, J. C. Green and N. Hazari, J. Am. Chem. Soc., 2006, 128, 9502; (c) N. Tsoureas, O. T. Summerscales, F. G. N. Cloke and S. M. Roe, Organometallics, 2013, 32, 1353.

20 (a) H. Werner, Coord. Chem. Rev., 1982, 43, 165-185; (b) K. K. Pandey, Coord. Chem. Rev., 1997, 140, 37-114.
21 C. J. Windorff and W. J. Evans, Organometallics, 2014, 33, 3786-3791.

22 S. Fortier, N. Kaltsoyannis, G. Wu and T. W. Hayton, J. Am. Chem. Soc., 2011, 133, 14224-14227.

23 D. S. J. Arney and C. J. Burns, J. Am. Chem. Soc., 1993, 115, 9840-9841.

24 A. J. Lewis, K. C. Mullane, E. Nakamaru-Ogiso, P. J. Carroll and E. J. Schelter, Inorg. Chem., 2014, 53, 6944-6953.

25 J. A. Higgins, F. G. N. Cloke and S. M. Roe, Organometallics, 2013, 32, 5244-5252.

$26 \nu_{(\mathrm{U}=\mathrm{O})}$ could not be unequivocally assigned as it coincides with stretches attributed to the TIPS groups.

27 C. Boisson, J. C. Berthet, M. Lance, M. Nierlich and M. Ephritikine, J. Organomet. Chem., 1997, 548, 9-16.

28 H. Aslan, J. Förster, K. Yünlü and R. D. Fischer, J. Organomet. Chem., 1988, 355, 79.

29 (a) M. Schultz, C. J. Burns, D. J. Schwartz and R. A. Andersen, Organometallics, 2000, 19, 781-789; (b) W. J. Evans, L. A. Hughes and T. P. Hanusa, Organometallics, 1986, 5, 1285.

30 A. E. Guiducci, C. L. Boyd and P. Mounford, Organometallics, 2006, 25, 1167-1187.

31 A. S. P. Frey, F. G. N. Cloke, M. P. Coles and P. B. Hitchcock, Chem.-Eur. J., 2010, 16, 9446.

32 Heating to higher temperature resulted in the formation of a tuck-in complex, see ref. 29.

33 The identity of (7) was confirmed by independent synthesis from $\left\{\mathrm{U}\left[\eta^{8}-\mathrm{C}_{8} \mathrm{H}_{6}\left(1,4-\mathrm{Si}\left({ }^{\mathrm{i}} \mathrm{Pr}\right)_{3}\right)_{2}\right]\left(\eta^{5}-\mathrm{Cp}^{\mathrm{Me}_{5}}\right) \mathrm{Cl}\right\} \quad$ (8) and $\mathrm{NaOSiMe}_{3}$ in THF. Its formulation was unambiguously confirmed by single crystal XRD. For more details and a brief discussion of metric parameters see the ESI. $\dagger$

34 A. R. Fox and C. C. Cummins, J. Am. Chem. Soc., 2009, 131, 5716-5717.

35 The $\nu(\mathrm{U} \equiv \mathrm{N})$ could not be unequivocally assigned as it coincides with stretches attributed to the TIPS groups.

36 D. R. Kindra and W. J. Evans, Chem. Rev., 2014, 114, 88658882.

37 L. Maria, I. C. Santos, V. R. Souza and J. Marçalo, Inorg. Chem., 2015, 54, 9115-9126.

38 C. Eaborn, M. S. Hill, P. B. Hitchcock and J. D. Smith, Organometallics, 2000, 19, 5780-5783.

39 C. R. Graves and J. L. Kiplinger, Chem. Commun., 2009, 26, 3831.

40 A.-C. Schimdt, F. W. Heinemann, W. W. Lukens and K. Meyer, J. Am. Chem. Soc., 2014, 136, 11980-11993.

41 (a) B. Masci and P. Thuéry, CrystEngComm, 2007, 9, 582-590; (b) P. Thuéry, B. Masci, M. Takimoto and T. Yamato, Inorg. Chem. Commun., 2007, 10, 795-799; (c) C. Nocton, P. Horegald, V. Vetere, J. Pécaut, L. Dubois, P. Maldivi, N. M. Edelstein and M. Mazzanti, J. Am. Chem. Soc., 2010, 132, 495-508. 